\title{
Determination of Major and Minor Elements in Maltese Sheep, Goat and Cow Milk Using Microwave Plasma-Atomic Emission Spectrophotometry
}

\author{
Ritianne Spiteri ${ }^{1} \&$ Everaldo Attard ${ }^{1}$ \\ ${ }^{1}$ Division of Rural Sciences and Food Systems, Institute of Earth Systems, University of Malta, Msida, Malta \\ Correspondence: Everaldo Attard, Division of Rural Sciences and Food Systems, Institute of Earth Systems, \\ University of Malta, Msida, MSD2080, Malta. Tel: 356-2340-2321/2. E-mail: everaldo.attard@um.edu.mt
}

Received: May 24, 2017

Accepted: June 20, 2017 Online Published: July 15, 2017

doi:10.5539/jas.v9n8p43

URL: https://doi.org/10.5539/jas.v9n8p43

\begin{abstract}
The mineral content of milk from sheep, goats and cows bred in Malta and Gozo were determined for the first time. Two hundred and twenty samples were collected from cow, sheep and goat farms in Malta and Gozo. Ten macro and micro minerals were analysed, using microwave plasma-atomic emission spectrophotometry.

No significant differences were observed between localities for the metals in the ruminant milk. Three micro minerals, $\mathrm{Mn}, \mathrm{Cr}$ and $\mathrm{Cd}$ were not detected in the three milk types. However, most metals differed significantly between ruminants. Potassium was highest in cow milk, while Ca was significantly the highest in sheep milk. The other metals occurred at much lower concentrations. For the micro minerals, sheep milk exhibited the highest concentrations for $\mathrm{Fe}, \mathrm{Mg}$ and $\mathrm{Cu}$ while cow milk showed the highest values for $\mathrm{Zn}$ and Ba. Principal component analysis revealed the separation of the cow and sheep milk samples into two distinct clusters, while the goat milk samples were scattered across the two clusters. This shows the distinctiveness of the sheep milk over the other two milk types.
\end{abstract}

Keywords: dairy ruminants, elemental analysis, milk, Malta

\section{Introduction}

The Maltese archipelago is situated at the centre of the Mediterranean Sea. It consists mainly of three inhabited islands: Malta, Gozo and Comino. The two main islands, Malta and Gozo, cover an area of approximately 300 $\mathrm{km}^{2}$ and $100 \mathrm{~km}^{2}$, respectively. On these islands, there are five dairy goat breeds which are the Maltese, the Saanen, the Alpine, the Girgentana and the Cross-Breed and with regards to dairy sheep, there are the Maltese, the East Friesian, the Comisana and the Cross-Breed. However the most common dairy breeds for both sheep and goats are the Cross-Breed, a hybrid cross between the Maltese and the East Friesian in the case of sheep and a hybrid cross between the Maltese and Saanen or Alpine for goats. There are four dairy cattle breeds which are the Jersey, the Brown Swiss and the Estonian Red Cattle and the Holstein-Frisian, the latter being the most common breed present on dairy cow farms. Dairy farms are distributed all around the Maltese Islands. According to the 'Malta Veterinary and Phytosanitary Regulation Directorate' (personal communication, 2015), in November 2014 in Malta there were approximately 85 dairy cow farms and approximately 1339 farms that involve dairy sheep and goats while in Gozo there were approximately 35 dairy cow farms and approximately 561 farms rearing dairy sheep and goat.

According to Pereira (2014), the chemical characteristics of cow milk are highly dependent on the type of farming system used, the type of diet provided to the livestock, location of farm, breed, genetics and stage of lactation. Generally, the composition of cow milk consists of $87 \%$ water, $4 \%$ to $5 \%$ lactose, $3 \%$ protein, $3 \%$ to $4 \%$ fat, $0.8 \%$ minerals and $0.1 \%$ vitamins (Pereira, 2014). One of the main benefits of cow milk is the ability of the cream to separate quickly from the liquid due to the milk's big fat globules (Gallier et al., 2011).

As in cows, characterisation of small ruminant milk also depends on several factors, such as reproduction, genetics, breeds, health status of animal, socio-economical environment and type of diet provided (Carloni et al., 2010; Zervas \& Tsiplakou, 2011). The majority of sheep milk is converted into cheese and hence optimum milk quality is essential to obtain high-quality distinctive cheeses. According to Domagala (2009), there is a marked difference in sheep milk composition when compared to cow and goat milk. Moreover, sheep milk consists of 
higher amounts of total solids, fats, lactose and ash. This is also supported by Zervas and Tsiplakou (2011) who suggest that sheep milk may have a higher amount of vitamins A, B and E, Calcium, Phosphorus, Potassium and Magnesium in comparison to cow milk. Another beneficial aspect of sheep milk is that its fat globules are smaller than those of cow milk and hence sheep milk is more easily digested (Carloni et al., 2010).

Popularity of goat milk and associated products is continuously increasing especially in developed countries. According to Ribeiro and Ribeiro (2010), this is probably due to increased marketing of the therapeutic properties of goat milk especially among persons who are allergic to cow milk. Although goat milk does not differ significantly from the composition of cow milk in terms of total solids, protein, fat and lactose, there is a marked difference in the structure, composition and size of casein micelles (Domagala, 2009). This is also supported by Silanikove et al. (2010), who also point out that the smaller size of the fat globules in goat milk contributes to a softer texture in goat dairy products optimising palatability.

Due to its chemical and sensorial characteristics, together with its microbiological traits and variousness, Pirisi et al. (2011) state that milk deriving from sheep and goats is especially used for cheese making particularly around the Mediterranean basin, namely in France, Italy, Spain and Greece. In Malta and Gozo, dairy cows, sheep and goats are reared primarily for their milk which is either used for own consumption, sold to dairy processing plants for the production of dairy products or used for the production of traditional homemade cheeselets, particularly sheep milk. Cheese making usually takes place on farm or in a room that is close to the farm and traditional cheeses in the mentioned countries except for Malta (until now) are protected by the Protected Designation of Origin (PDO) and the Protected Geographic Indication (PGI) certification.

With regards to the introduction of innovative products on the market, according to Escareño et al. (2013), dairy goat production is common in the Mediterranean basin particularly in France, Spain, Greece and Italy and its economical importance is highlighted by the fact that even though Europe holds only $5.1 \%$ of the world's dairy goat herds, it produces $15 \%$ of the world's goat milk. However in Malta, even though goat milk was very popular in the 1800s', according to Wyatt (2009) its popularity declined after the Brucellosis outbreak in the 1880 s' that was particularly linked with consumption of raw goat milk. However, adequate pasteurisation eliminates this problem and hence, considering the unique characteristics of goat milk and increase in consumers' demand; it would be sustainably viable to start a local market campaign on goat milk.

The aim of this study is to evaluate the mineral content of milk deriving from cow, sheep and goat farms in Malta and Gozo and to determine any significant differences in milk between the two islands. As small ruminant farms are the most predominant on the islands, sheep and goat milk was analysed for comparative purposes against cow milk.

\section{Materials and Methods}

\subsection{Milk Samples}

During 2013 and 2014, 220 milk samples were collected from dairy cow and small ruminant farms in Malta and Gozo. The pooled samples were collected from the bulk tank or from the pail, depending on the farm's milking procedure. The aim of pooled samples collection rather than collecting samples from individual heads was to have a general idea on the milk composition of Maltese and Gozitan farms. There were 30 farmers who provided more than one type of milk, reducing the number of farms sampled to 190. The number of samples collected from cow, sheep and goat herds were 102, 89 and 29 samples, respectively. The samples were collected between October 2013 and March 2014 since during these months, small ruminants are in their lactating phase.

\subsection{Sample Preparation}

The method described by Güler (2007), for acid digestion prior to mineral analysis, was followed with slight modifications. Briefly, milk samples $(2 \mathrm{ml})$ were carefully transferred to labelled porcelain crucibles and treated with $5 \% \mathrm{HNO}_{3}$. The cups were placed on a hot plate under the laminar cabinet for approximately 75 minutes until the solution was dried out. The resultant acid-treated samples were then subjected to a temperature of $500{ }^{\circ} \mathrm{C}$ for a period of 4 hours. The ash samples were then dissolved in $5 \mathrm{ml}$ of $5 \%$ nitric acid solution and transferred to $50 \mathrm{ml}$ volumetric flasks. The volumes were topped with de-ionised water. All crucibles, glassware and plasticware used were soaked in a 5\% nitric acid solution overnight, and then rinsed with deionised water.

\subsection{Mineral Analysis}

An Agilent 4100 MP-AES (Agilent Technologies, Santa Clara, CA, USA) was used. Calibration curves for the metals were obtained by preparing serial dilutions from the Agilent Technologies - ICP-OES wavelength calibration solution. For each mineral, the wavelength was selected manually at the appropriate background 
positions for each mineral peak. The instrument setup and general experimental conditions are summarised in Table 1. The samples were analysed in triplicates.

Table 1. MP-AES configuration and operating conditions

\begin{tabular}{ll}
\hline Pump speed (rpm) & 15 \\
Sample introduction & manual \\
Stabilization time (s) & 15 \\
Uptake time (s) & 15 (Using fast pump) \\
Nebulizer & Agilent One-Neb Pneumatic concentric nebulizer \\
Spray Chamber & Double-pass glass cyclonic spray chamber for Agilent MP-AES \\
Elements, wavelengths (nm) & $\mathrm{Ba}(455.403), \mathrm{Ca}(616.217), \mathrm{Cd}(228.802), \mathrm{Cr}(425.433), \mathrm{Cu}(324.754)$, \\
& $\mathrm{Fe}(259.940), \mathrm{K}(766.491), \mathrm{Mg}(518.360), \mathrm{Mn}(403.076), \mathrm{Zn}(213.857)$ \\
\hline
\end{tabular}

\subsection{Statistical Analysis}

The data concerning the cow, sheep and goat milk of the Maltese populations, were subjected to One-way analysis of Variance with the Bonferroni post-hoc test by using Prism v. 5 (GraphPad Software, Inc., USA) in order to determine differences in the elemental content values for the species and locations interactions. Principal Component Analysis and Pearson correlations were conducted on all samples, using XLSTAT v.2014.4.04 (http://www.xlstat.com, Addinsoft) to determine any clustering for the species and locations. The significance level was considered at $\mathrm{p}<0.05$.

\section{Results}

The mineral analysis for the cow, sheep and goat milk obtained from farms in Malta and Gozo, are illustrated in Table 2 .

Table 2. Comparison of the Metallic Content between the milk of the three species in Malta and Gozo in mg/L

\begin{tabular}{|c|c|c|c|c|c|c|c|c|c|}
\hline & \multicolumn{3}{|c|}{ Malta and Gozo } & \multicolumn{3}{|c|}{ Malta } & \multicolumn{3}{|c|}{ Gozo } \\
\hline & Cows & Sheep & Goats & Cows & Sheep & Goats & Cows & Sheep & Goats \\
\hline $\mathrm{Ca}$ & $873 \pm 235.9$ & $1249 \pm 181.7$ & $922 \pm 92.6$ & $836 \pm 210.2$ & $1257 \pm 207.8$ & $920 \pm 96.2$ & $949 \pm 267.7$ & $1234 \pm 106.2$ & $926 \pm 90.3$ \\
\hline $\mathrm{Mg}$ & $106 \pm 26.5$ & $169 \pm 29.9$ & $141 \pm 20.2$ & $101 \pm 22.6$ & $171 \pm 33.5$ & $142 \pm 23.1$ & $116 \pm 30.9$ & $166 \pm 19.8$ & $140 \pm 14.1$ \\
\hline $\mathrm{K}$ & $1275 \pm 316.3$ & $937 \pm 169.5$ & $1216 \pm 128.2$ & $1283 \pm 285.3$ & $971 \pm 167.7$ & $1218 \pm 132.4$ & $1258 \pm 374.7$ & $864 \pm 151.9$ & $1214 \pm 126.8$ \\
\hline $\mathrm{Fe}$ & $0.79 \pm 0.74$ & $0.98 \pm 0.53$ & $0.67 \pm 0.12$ & $0.77 \pm 0.87$ & $1.07 \pm 0.58$ & $0.69 \pm 0.12$ & $0.81 \pm 0.37$ & $0.78 \pm 0.33$ & $0.62 \pm 0.13$ \\
\hline $\mathrm{Zn}$ & $4.22 \pm 0.886$ & $3.82 \pm 0.92$ & $3.31 \pm 0.79$ & $4.11 \pm 0.79$ & $3.82 \pm 0.86$ & $3.29 \pm 0.96$ & $4.45 \pm 1.02$ & $3.38 \pm 1.05$ & $1.06 \pm 0.33$ \\
\hline $\mathrm{Ba}$ & $1.04 \pm 0.49$ & $0.64 \pm 0.32$ & $0.75 \pm 0.91$ & $1.03 \pm 0.48$ & $0.65 \pm 0.33$ & $0.58 \pm 0.50$ & $1.06 \pm 0.52$ & $0.61 \pm 3.02$ & $1.07 \pm 1.38$ \\
\hline $\mathrm{Cu}$ & $0.23 \pm 0.13$ & $0.37 \pm 0.15$ & $0.34 \pm 0.08$ & $0.20 \pm 0.13$ & $0.36 \pm 0.15$ & $0.34 \pm 0.08$ & $0.27 \pm 0.11$ & $0.39 \pm 0.13$ & $0.34 \pm 0.08$ \\
\hline
\end{tabular}

No significant difference in the mean concentration of Fe in cow and goat milk between Malta and Gozo was observed; however a significant difference was observed in the Fe content of sheep milk between the two islands $(\mathrm{p}<0.05)$. Interspecies differences were significant; with sheep milk Fe being higher as compared to cow and goat milk Fe content $(\mathrm{p}<0.05)$.

The mean concentration of $\mathrm{Ca}$ in sheep and goat milk between Malta and Gozo did not vary significantly; however a significant difference was observed between the Ca concentrations of cow milk between the two islands $(\mathrm{p}<0.05)$. Interspecies differences were significant; with sheep milk $\mathrm{Ca}$ being higher as compared to goat and cow milk Ca content $(\mathrm{p}<0.0001)$.

There was no significant difference in the mean concentration of $\mathrm{Mg}$ in sheep and goat milk between Malta and Gozo however a significant difference was observed in $\mathrm{Mg}$ concentration in cow milk between the two islands ( $\mathrm{p}$ $<0.005$ ). For this mineral, interspecies differences were significant; with sheep milk Mg being highest followed by goat and cow milk Mg content $(\mathrm{p}<0.0001)$.

No significant differences in the mean concentration of $\mathrm{K}$ in cow and goat milk between Malta and Gozo were observed, however a significant difference was observed in the mean $\mathrm{K}$ content of sheep milk between the two 
islands ( $\mathrm{p}<0.005$ ). As opposed to the previous minerals, although interspecies differences were significant cow and goat milk K contents were higher as compared to sheep milk K content $(\mathrm{p}<0.0001)$.

The mean concentrations of $\mathrm{Zn}$ and $\mathrm{Ba}$ did not vary significantly with location. However interspecies differences were significant with cow milk $\mathrm{Zn} / \mathrm{Ba}$ being the highest followed by sheep and goat milk $\mathrm{Zn} / \mathrm{Ba}$ contents ( $\mathrm{p}<$ $0.0001)$.

There was no significant difference in the mean concentration of $\mathrm{Cu}$ in sheep and goat milk between Malta and Gozo; however a significant difference was observed in milk $\mathrm{Cu}$ concentration in cow milk between the two localities $(\mathrm{p}<0.05)$. Interspecies differences were significant with sheep and goat milk $\mathrm{Cu}$ being higher as compared to cow milk $\mathrm{Cu}$ concentration $(\mathrm{p}<0.0001)$.

Factor analysis using principal components was used to identify latent traits within the data. Pearson correlation (Table 3) revealed that the only related elements were $\mathrm{Mg}$ and $\mathrm{Ca}(\mathrm{r}=0.868)$. Two latent factors had an eigenvalue greater than 1 , which together explained $57.91 \%$ of the total variance (Figure 1). The factor loadings plot (Figure 1a) demonstrates the different groups of variables. For the first factor, the factor loadings of $\mathrm{Mg}, \mathrm{Ca}$ and $\mathrm{Cu}$ were positive. The second factor weighed heavily on $\mathrm{K}$ and $\mathrm{Zn}$, with lower weightings on $\mathrm{Ba}$.

Figure $1 \mathrm{~b}$ demonstrates the factor scores of the two latent factors. Factor 1, on the horizontal axis, demonstrates the clustering of sheep milk on the right side at the centre of the scatter plot, while the cow milk samples scattered more the left side. The goat milk samples exhibited scattering with no significant clustering. This demonstrates the distinction of the sheep and cow milk having different elemental constitution. This confirms the ANOVA analysis discussed above.

Table 3. Pearson correlation matrix for the studied parameters

\begin{tabular}{lllllll}
\hline Variables & $\mathrm{Fe}$ & $\mathrm{Ca}$ & $\mathrm{Mg}$ & $\mathrm{K}$ & $\mathrm{Zn}$ & $\mathrm{Ba}$ \\
\hline $\mathrm{Ca}$ & 0.211 & & & & & \\
$\mathrm{Mg}$ & 0.209 & $\mathbf{0 . 8 6 8}$ & & & & \\
$\mathrm{K}$ & -0.013 & -0.006 & -0.146 & & & \\
$\mathrm{Zn}$ & 0.177 & 0.375 & 0.103 & 0.481 & & \\
$\mathrm{Ba}$ & 0.003 & -0.047 & -0.116 & 0.351 & 0.148 & \\
$\mathrm{Cu}$ & 0.094 & 0.453 & 0.398 & -0.113 & 0.031 & 0.008 \\
\hline
\end{tabular}

Note. Values in bold are the significant Pearson correlation coefficients $(\mathrm{p}<0.05)$.
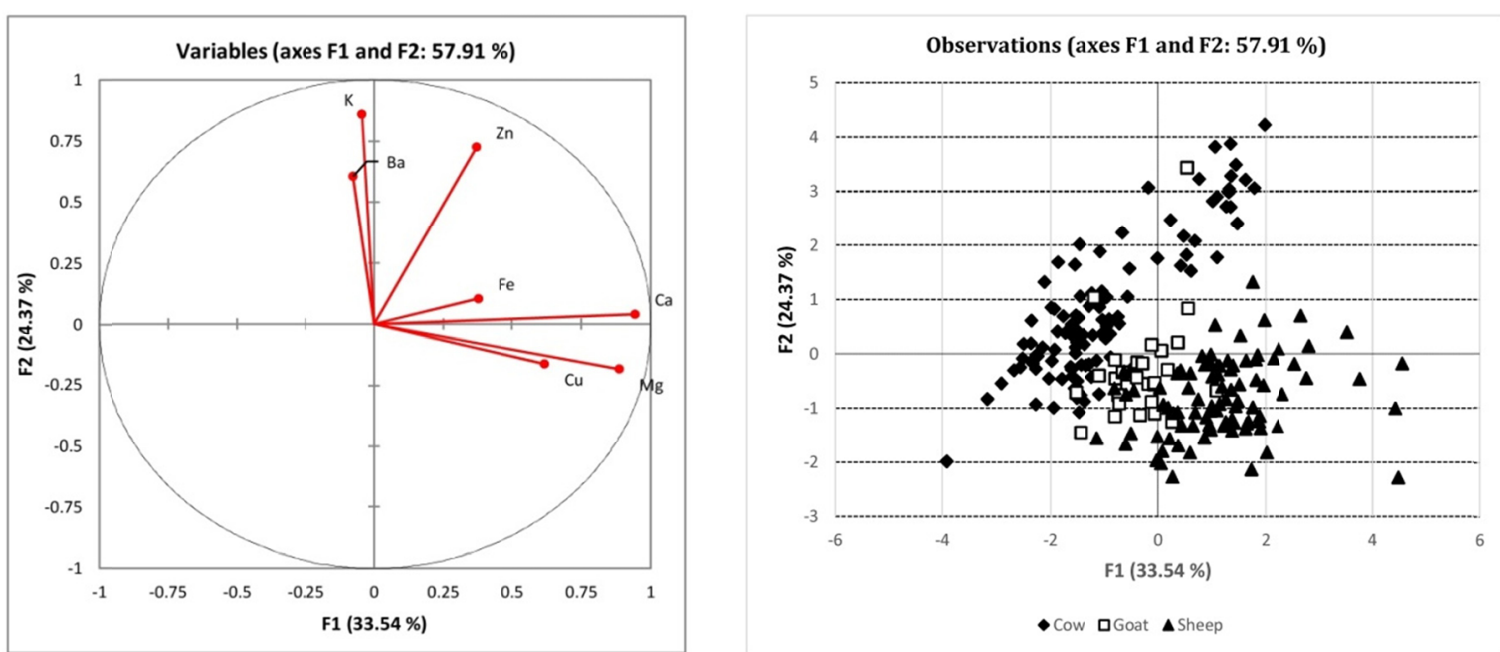

Figure 1. (a) The factor loading plot demonstrating the different groups of variables; (b) The factor scores of the two latent factors

\section{Discussion}

From the ninety-two naturally occurring elements, about thirty metals and metalloids may be toxic to humans. These are Be, B, Li, Al, Ti, V, Cr, Mn, Co, Ni, Cu, As, Se, Sr, Mo, Pd, Ag, Cd, Sn, Sb, Te, Cs, Ba, W, Pt, Au, Hg, 
$\mathrm{Pb}$, and $\mathrm{Bi}$ (Morais et al., 2012). The metal content in milk and dairy products can be categorized into essential elements $(\mathrm{Fe}, \mathrm{Cu}$ and $\mathrm{Zn}$, in low doses) and toxic metals $(\mathrm{Pb}$ and $\mathrm{Cd})$. The latter may have adverse impacts on human health even at low concentrations. Micro nutrient are crucial both for humans and livestock well-being and even though they are required in minimum quantities, they are cofactors of enzymes and proteins related to a number of physiological, biochemical and metabolic processes that are essential for proper growth and for the enhancement of productive performance (Yatoo et al., 2013).

The average Ca content for the cow, sheep and goat milk samples in this study are shown in Table 2. It is worth noting that the sheep $\mathrm{Ca}$ content is higher than the cow and goat $\mathrm{Ca}$ contents. This was observed in other studies namely by Bornaz et al. (2009) with concentrations of 2155, 1245 and $1205 \mathrm{mg} / \mathrm{L}$, respectively. As with other studies, the current $\mathrm{Ca}$ content of milk for the three species was relatively lower. Sola-Larrañaga and Navarro-Blasco (2009) together with Tsioulpas et al. (2007) reveal a cow milk Ca mean content of $970 \mathrm{mg} / \mathrm{L}$ and $1450 \mathrm{mg} / \mathrm{L}$ respectively, Mayer and Fiechter (2012) determined sheep and goat Ca mean contents of $1846 \mathrm{mg} / \mathrm{L}$ and $1288 \mathrm{mg} / \mathrm{L}$, respectively. Calcium in milk is generally distributed between the micellar and aqueous phases at a mean concentration of $1200 \mathrm{mg} / \mathrm{L}$ (Gaucheron, 2011). In the micellar phase, it is linked with the phosphoseryl residues of caseins while in the aqueous phase, it is able to bind to whey proteins or inorganic forms of phosphate-forming salts (McGann et al., 1983). Calcium is a natural mineral essential for both livestock and humans. Studies (Pereira, 2014) show that an adequate calcium intake in humans reduces risk to develop osteoporosis and enhance bone density. The World Health Organisation associates a low calcium intake (below 400-500 mg/day) with increased fracture risks among older men and women especially in countries with high osteoporotic fracture incidence (WHO \& FAO, 2003).

In the present study, $\mathrm{K}$ was significantly higher particularly in cow and goat species with respect to sheep milk $\mathrm{K}$ content (Table 2). The cow milk K content quoted by Sola-Larranaga et al. (2009) (1344 mg/L) was similar to the present value. However, Mayer and Fiechter (2012) suggested contents of 1248 and $2015 \mathrm{mg} / \mathrm{L}$, in sheep and goat milk while Raynal-Ljutovac et al. (2008) suggested K values of $1500 \mathrm{mg} / \mathrm{L}$ in cow, $1360-1400 \mathrm{mg} / \mathrm{L}$ in sheep and $1900 \mathrm{mg} / \mathrm{L}$ in goat milk. This trend is also exhibited in the present study in which case the sheep milk $\mathrm{K}$ content is lower than for the other ruminants. This may reflect a higher $\mathrm{K}$ content in cheeses derived from cow as compared to goat and sheep milk (González-Martín et al., 2011). According to researchers He and MacGregor (2008), increasing K consumption is beneficial for human health. World Health Organisation (2012) suggests a K intake of at least $3510 \mathrm{mg} /$ day for adults.

The cow milk Mg content was higher (158.64 mg/L) for Tsioulpas et al. (2007) than the present study (Table 2) but was within the range of 77.120-141.915 mg/L quoted by Perween et al. (2013). Sheep and goat milk contained higher Mg values (169.55 \pm 29.86 and $141.06 \pm 20.18 \mathrm{mg} / \mathrm{L}$, respectively). In other studies, sheep milk demonstrated a predominant $\mathrm{Mg}$ content of $192 \mathrm{mg} / \mathrm{L}$ as compared to goat $(138 \mathrm{mg} / \mathrm{L})$ by Mayer and Fiechter (2012) and to cow Mg milk (91.8 mg/L) by Sola-Larrañaga et al. (2009). Physicochemical conditions affect Mg levels in milk (Gaucheron, 2011). Mg in the micellar phase is dissolved in the aqueous phase of acidified milk. Magnesium is one of the most essential micronutrients and it is vital for the proper functioning of the immune system. It is the second most abundant divalent cation according to Tam et al. (2003 and a critical co-factor in as many as 300 enzymatic reactions; Mg deficiency will diminish immune function and can potentially affect every organ of the body (Wu \& Veillette, 2011). The WHO (2001) recommends a Mg intake of $220 \mathrm{mg} / \mathrm{d}$ for adult females and $260 \mathrm{mg} / \mathrm{d}$ for adult men.

In general, most studies showed a very low $\mathrm{Cu}$ cow milk content $(0.004-0.070 \mathrm{mg} / \mathrm{L})$ as quoted by Perween et al. (2013) and Sola-Larrañaga et al. (2009). The Cu milk content in the present study for the three species was comparable to the study by Brescia et al. (2003) $(0.31-0.32 \mathrm{mg} / \mathrm{L})$. Although the present study reveals a higher $\mathrm{Cu}$ content in sheep milk than in the other milk samples, Al-Wabel (2008) states that the cow milk has a predominant amount of $\mathrm{Cu}(1.875 \mathrm{mg} / \mathrm{L})$ as compared to the sheep and goat $\mathrm{Cu}$ milk content $(0.645$ and 0.5938 , respectively).

The local cow milk contained mean Fe content within the range of various cow milk samples analysed in other studies. The content goes in accordance with the values $(0.580-7.320 \mathrm{mg} / \mathrm{L})$ obtained by Perween et al. (2013). However other studies quoted levels higher and lower than the local Fe content of milk. Brescia et al. (2003) determined contents of 1.18-1.27 ppm. On the other hand, Sola-Larranaga et al. (2009) declared a concentration of $0.290 \mathrm{mg} / \mathrm{L}$. As in the current study, Moreno-Rojas et al. (1993) demonstrated predominant Fe content in sheep milk, followed by goat and then cow milk $(0.427,0.417$ and $0.167 \mathrm{mg} / \mathrm{L}$, respectively).

The studies by Sola-Larrañaga et al. (2009) (4.631 mg/L) and Perween et al. (2013) demonstrated comparable $\mathrm{Zn}$ values for cow milk (2.080-4.872 $\mathrm{mg} / \mathrm{L})$ to this present study. Brescia et al. (2003) quoted high $\mathrm{Zn}$ content in 
cow milk (> $16.19 \mathrm{mg} / \mathrm{L}$ ). Comparing the three species Al-Wabel (2008) and Moreno-Rojas et al. (1993) demonstrated that sheep milk contains the highest $\mathrm{Zn}$ contents over goat and cow milk. In this current study the highest $\mathrm{Zn}$ content was found in cow milk $(4.22 \pm 0.886 \mathrm{mg} / \mathrm{L})$ compared to sheep and goat milk $(3.82 \pm 0.92$ and $3.31 \pm 0.79 \mathrm{mg} / \mathrm{L}$, respectively). Zinc is present primarily in the micellar phase combined with casein (Gaucheron, 2011; Pereira, 2014). Copper and Fe are microelements in milk and its products found only in small amounts (Gaucheron, 2011). According to the World Health Organization (2001) the recommended daily dietary intake for $\mathrm{Zn}, \mathrm{Fe}$ and $\mathrm{Cu}$ are approximately $10.5-14 \mathrm{mg} /$ day, 14.4-43.1 mg/day and $900 \mu \mathrm{g} /$ day, respectively).

Manganese was undetectable in this present study for all three milk types. In fact, milk is a poor source of Mn with approximately 0.33 and $0.21 \mathrm{mg} / \mathrm{L}$ in goat and cow milk respectively, according to Park and Haenlein (2008). Zamberlin et al. (2012) stated that Mn acts as a co-factor for many enzymes and is involved in the synthesis of complex polysaccharides. Even though the body is only able to absorb only 3 to $5 \%$ of the dietary intake of $\mathrm{Mn}$, no studies were carried out to confirm any health disorders associated with Mn deficiency. Likewise, Cr was undetectable too. It has been demonstrated by Cocho et al. (1992) that the $\mathrm{Cr}$ content ranged between 0.005 and $0.015 \mathrm{mg} / \mathrm{L}$ in cow milk. Chromium intensifies insulin performance and therefore is essential in the metabolism of carbohydrates, fats and proteins; however according to several studies no interaction between $\mathrm{Cr}$ and insulin has been yet identified (WHO, 1996; Stearns, 2000).

Cadmium was completely absent in the current milk samples. However, in a study conducted by Rahimi (2013), results demonstrated higher concentrations of $\mathrm{Cd}$ in sheep milk when compared to the other ruminants. This is not unlikely given that generally sheep milk contains a higher amount of minerals than cow and goat milk. In their study Rodríguez Rodríguez et al. (1999) discussed that Cd in cow milk samples was higher when protein content in milk increased and also mentioned that in other studies $\mathrm{Cd}$ content was associated with the protein fraction (casein fraction) in milk. Cadmium is 1000 times more toxic than $\mathrm{Pb}$ however food poisoning due to $\mathrm{Cd}$ intoxication is rare, as the level in foods is usually very low (Moreno-Rojas et al., 2010). Environmental pollution has always been a problem and is significantly increasing due to industrial and agricultural emissions. Due to this, milk and milk products are continuously risking contamination especially from $\mathrm{Pb}$ and $\mathrm{Cd}$ which according to Suturović et al. (2014), are the most commonly-occurring heavy metals polluted environment.

\section{Conclusion}

This study revealed minor differences in milk mineral constitution between the farms in Malta and Gozo. However, differences were observed between the ruminants. The cow and sheep milk showed distinctive mineral characteristics but the goat milk converged with the other two milk types. This study serves as a basis to distinguish the milk types by their mineral constitution, hence revealing any possible adulteration of one type of milk from a species with another type from another species. These would also reflect the characterization of dairy products derived from different milk types based on their mineral contents. Subsequently, the traceability of the milk type can be achieved on this basis. This study also shows the mineral nutritional value of the three milk types.

\section{References}

Al-Wabel, N. A. (2008). Mineral contents of milk of cattle, camels, goats and sheep in the central region of Saudi Arabia. Asian Journal of Biochemistry, 3, 373-375. https://doi.org/10.3923/ajb.2008.373.375

Bornaz, S., Sahli, A., Attalah, A., \& Attia, H. (2009). Physicochemical characteristics and renneting properties of camels' milk: A comparison with goats', sheep' and cows' milks. International Journal of Dairy Technology, 62, 505-513. https://doi.org/10.1111/j.1471-0307.2009.00535.x

Brescia, M. A., Caldarola, V., Buccolieri, G., Dell’ Atti, A., \& Sacco, A. (2003). Chemometric Determination of the Geographical Origin of Cow Milk using ICP-OES Data and Isotopic Rations: A Preliminary Study. Italian Journal of Food Science, 15, 329-336.

Carloni, M., Fedeli, D., Roscioni, T., Gabbianelli, R., \& Falcioni, G. (2010). Seasonal variation of fat composition in sheep's milk from areas of central Italy. Mediterranean Journal of Nutrition and Metabolism, 3, 55-60. https://doi.org/10.1007/s12349-009-0057-0

Cocho, J. A., Cervilla, J. R., Rey-Goldar, M. L., Fdez-Lorenzo, J. R., \& Fraga, J. M. (1992). Chromium content in human milk, cow's milk, and infant formulas. Biological Trace Element Research, 32, 105-107. https://doi.org/10.1007/BF02784593

Domagala, J. (2009). Instrumental texture, syneresis and microstructure of yoghurts prepared from goat, cow and sheep milk. International Journal of Food Properties, 12, 605-615. https://doi.org/10.1080/1094291080 1992934 
Escareño, L., Salinas-Gonzalez, H., Wurzinger, M., Iñiguez, L., Sölkner, J., \& Meza-Herrera, C. (2013). Dairy goat production systems: Status quo, perspectives and challenges. Tropical Animal Health and Production, 45, 17-34. https://doi.org/10.1007/s11250-012-0246-6

Gallier, S., Gordon, K. C., Jiménez-Flores, R., \& Everett, D. W. (2011). Composition of cow milk fat globules by confocal Raman microscopy. International Dairy Journal, 21, 402-412. https://doi.org/10.1016/j.idairyj. 2011.01.008

Gaucheron, F. (2011). Milk and Dairy Products: A Unique Micronutrient Combination. The Journal of the American College of Nutrition, 30, 400S-9S. https://doi.org/10.1080/07315724.2011.10719983

González-Martín, I., Hernández-Hierro, J. M., Revilla, I., Vivar-Quintana, A., \& Lobos Ortega, I. (2011). The mineral composition ( $\mathrm{Ca}, \mathrm{P}, \mathrm{Mg}, \mathrm{K}, \mathrm{Na})$ in cheeses (cow's, sheep's and goat's) with different ripening times using near infrared spectroscopy with a fibre-optic probe. Food Chemistry, 127, 147-152. https://doi.org/ 10.1016/j.foodchem.2010.12.114

Güler, Z. (2007). Levels of 24 minerals in local goat milk, its strained yoghurt and salted yoghurt (tuzlu yoğurt). Small Ruminant Research, 71, 130-137. https://doi.org/10.1016/j.smallrumres.2006.05.011

He, F. J., \& MacGregor, G. A. (2008). Beneficial effects of potassium on human health. Physiologia Plantarum, 133, 725-735. https://dx.doi.org/10.1111/j.1399-3054.2007.01033.x

Mayer, H. K., \& Fiechter, G. (2012). Physical and chemical characteristics of sheep and goat milk in Austria. International Dairy Journal, 24, 57-63. https://doi.org/10.1111/j.1399-3054.2007.01033.x

McGann, T. C. A., Buchheim, W., Kearney, R. D., \& Richardson, T. (1983). Composition and ultrastructure of calcium phosphate-citrate complexes in cow milk systems. Biochimica et Biophysica Acta - General Subjects, 760, 415-420. https://doi.org/10.1016/0304-4165(83)90383-5

Morais, S., Garcia, F., \& de Lourdes Pereira, C. M. (2012). Heavy metals and human health. In J. Oosthuizen (Ed.), Environmental Health-Emerging Issues and Practic (pp. 227-246). InTech. https://doi.org/ $10.5772 / 29869$

Moreno-Rojas, R., Amaro-Lopez, M. A., \& Zurera-Cosano, G. (1993). Micronutrients in natural cow, sheep and goat milk. International Journal of Food Sciences and Nutrition, 44, 37-46. https://doi.org/10.3109/ 09637489309017421

Moreno-Rojas, R., Sánchez-Segarra, P. J., Camara-Martos, F., \& Amaro-Lopez, M. (2010). Heavy metal levels in Spanish cheeses: Influence of manufacturing conditions. Food Additives \& Contaminants: Part B, 3, 90-100. https://doi.org/10.1080/19440049.2010.491838

Park, Y. W., \& Haenlein, G. F. (2008). Handbook of milk of non-bovine mammals. Iowa; Blackwell Publishing.

Pereira, P. C. (2014). Milk nutritional composition and its role in human health. Nutrition, 30, 619-627. https://doi.org/10.1016/j.nut.2013.10.011

Perween, R., Bhutto, A., Ara, D., Shaukat, S. S., \& Haq, Q. (2013). Elucidation of physico-chemical characteristics and mycoflora of cow milk available in selected area of Karachi, Pakistan Journal of Applied Sciences and Environmental Management, 17, 259-265. https://doi.org/10.4314/jasem.v17i2.9

Pirisi, A., Comunian, R., Urgeghe, P. P., \& Scintu, M. F. (2011). Sheep's and goat's dairy products in Italy: Technological, chemical, microbiological, and sensory aspects. Small Ruminant Research, 101L, 102-112. https://doi.org/10.1016/j.smallrumres.2011.09.030

Rahimi, E. (2013). Lead and cadmium concentrations in goat, cow, sheep, and buffalo milks from different regions of Iran. Food Chemistry, 136, 389-391. https://doi.org/10.1016/j.foodchem.2012.09.016

Raynal-Ljutovac, K., Lagriffoul, G., Paccard, P., Guillet, I., \& Chilliard, Y. (2008). Composition of goat and sheep milk products: An update. Small Ruminant Research, 79, 57-72. https://doi.org/10.1016/ j.smallrumres. 2008.07.009

Ribeiro, A. C., \& Ribeiro, S. D. A. (2010). Specialty products made from goat milk. Small Ruminant Research, 89, 225-233. https://doi.org/10.1016/j.smallrumres.2009.12.048

Rodríguez Rodríguez, E. M., Delgado Uretra, E., \& Díaz Romero, C. (1999). Concentrations of cadmium and lead in different types of milk. Zeitschrift für Lebensmitteluntersuchung und - Forschung A, 208, 162-8. https://doi.org/10.1007/s002170050395 
Silanikove, N., Leitner, G., Merin, U., \& Prosser, C. G. (2010). Recent advances in exploiting goat's milk: Quality, safety and production aspects. Small Ruminant Research, 89, 110-124. https://doi.org/ 10.1016\%2Fj.smallrumres.2009.12.033

Sola-Larrañaga, C., \& Navarro-Blasco, I. (2009). Chemometric analysis of minerals and trace elements in raw cow milk from the community of Navarra, Spain. Food Chemistry, 112, 189-196. https://doi.org/10.1016/ j.foodchem.2008.05.062

Stearns, D. M. (2000). Is chromium a trace essential metal? BioFactors, 11, 149-162. https://doi.org/10.1002/ biof.5520110301

Suturović, Z., Kravić, S., Milanović, S., Đurović, A., \& Brezo, T. (2014). Determination of heavy metals in milk and fermented milk products by potentiometric stripping analysis with constant inverse current in the analytical step. Food Chemistry, 155, 120-125. https://doi.org/10.1016/j.foodchem.2014.01.030

Tam, M., Gomez, S., Gonzalez-Gross, M., \& Marcos, A. (2003). Possible roles of magnesium on the immune system. European Journal of Clinical Nutrition, 57, 1193-1197. https://doi.org/10.1038/sj.ejcn.1601689

Tsioulpas, A., Grandison, A. S., \& Lewis, M. J. (2007). Changes in physical properties of cow milk from the colostrum period to early lactation. Journal of Dairy Science, 90, 5012-5017. https://doi.org/10.3168/ jds.2007-0192

WHO and FAO Joint Expert Consultation. (2003). Diet, nutrition and the prevention of chronic diseases. World Health Organisation Technical Report Series, 916, i-viii.

WHO Human Vitamin and Mineral Requirements. (2001). Report of a joint FAO/WHO expert consultation Bangkok, Thailand. Corporate Document Repository.

WHO. (1996). Trace Elements in Human Nutrition and Health. Geneva, World Health Organisation.

WHO. (2012). Guideline: Potassium intake for adults and children. Geneva, World Health Organization.

$\mathrm{Wu}$, N., \& Veillette, A. (2011). Immunology: Magnesium in a signalling role. Nature, 475, 462-463. https://doi.org/10.1038/475462a

Wyatt, H. V. (2009). Brucellosis and Maltese goats in the Mediterranean. Journal of Maltese History, 1, 4-19.

Yatoo, M. I., Saxena, A., Deepa, P. M., Habeab, B. P., Devi, S., Jatav, R. S., \& Dimri, U. (2013). Role of trace elements in animals: A review. Veterinary World, 6, 963-7. https://doi.org/10.14202/vetworld.2013.963-967

Zamberlin, Š., Antunac, N., Havranek, J., \& Samaržija, D. (2012). Mineral elements in milk and dairy products. Mljekarstvo/Dairy, 62, 111-125.

Zervas, G., \& Tsiplakou, E. (2011). The effect of feeding systems on the characteristics of products from small ruminants. Small Ruminant Research, 101, 140-149. https://doi.org/10.1016/j.smallrumres.2011.09.034

\section{Copyrights}

Copyright for this article is retained by the author(s), with first publication rights granted to the journal.

This is an open-access article distributed under the terms and conditions of the Creative Commons Attribution license (http://creativecommons.org/licenses/by/4.0/). 